\title{
Digital Data Repository
}

National Cancer Institute

\section{Source}

National Cancer Institute. Digital Data Repository. NCI Thesaurus. Code C114457.

A storage location for digital data. 